\title{
National Identities, International Roles and the Legitimation of Climate Leadership: Germany and Norway compared
}

\begin{abstract}
The UNFCCC confers an obligation on developed states to lead in mitigation. This obligation challenges traditional conceptions of the modern state by calling forth a more outward looking state that is able to serve both the national and international community in the service of global climate protection. Yet the more sceptical theories of the ecological state suggest that climate leaders will only emerge if they can connect their climate strategy to the traditional state imperatives of economic growth or national security. Through a comparative discourse analysis, this article examines how the governments of Germany and Norway, both relative climate leaders with ongoing fossil fuel dependencies, have legitimated their climate policies and diplomacy. It finds that while both governments rely heavily on discourses of green growth they also construct national identities and international role conceptions that serve purposes beyond themselves.
\end{abstract}

Key words: climate leadership, national identity, international role conception, discourse analysis, Germany, Norway 


\section{Introduction}

As James Meadowcroft (2005) has pointed out, whereas the welfare state was largely a national creation, aided by cross-national policy transfer, the ecological state (by which he means the environmental responsibilities of the modern state) is increasingly an international creation in response to transboundary ecological problems, manifest in a growing raft of international environmental treaties, declarations, networks and associated discourses that confer differentiated responsibilities of developed and developing states. So while the aims of the welfare state can be pursued relatively independently of other states, 'the aims of the ecological state can only be secured through cooperative action with other states' $(2005,12-$ 13). This is especially pronounced in relation to the international climate regime, where the United Nations Framework Convention for Climate Change (UNFCCC) 1992 has conferred an obligation on developed countries to take the lead in mitigation, and to provide assistance with mitigation and adaptation to developing states, according to the principles of 'equity and common but differentiated responsibilities and respective capabilities' (hereafter CBDR). ${ }^{1}$ This interpretation calls forth a more outward looking state role conception and national imaginary that is able to serve both the national and other communities whose fates are tied in with decisions made by national policy makers (Eckersley 2004).

These are highly demanding environmental responsibilities that run against the grain of the traditional security and development purposes of the state and, not surprisingly, present a significant legitimation challenge for national governments of developed countries. The history of international and national climate politics has shown that developed states have responded to the principles of CBDR, and the associated call for climate leadership, with 
varying levels of enthusiasm ranging from acceptance, reinterpretation, subversion and outright rejection.

There is no shortage of realist, rationalist and critical Marxist theories in political theory and International Relations (IR) theory that are able to provide an explanation of why developed states would want to shirk, dispute or otherwise curtail the CBDR and otherwise avoid an ambitious mitigation strategy. This includes post-Marxists theories of the ecological state or eco-welfare state (Dryzek 1992; Hay 1996), which are generally sceptical about the capacity of states to sacrifice national economic imperatives in the name of environmental protection. These theories maintain that the state is not functionally capable of serving purposes beyond itself largely due to the state's enmeshment in the global capitalist economy and the overriding imperative of promoting capital accumulation to stay afloat in an increasingly competitive environment. More recent comparative research on green states and social movements by Dryzek et al (2003, especially Chapter 3), which is more neo-Weberian than neo-Marxist, has argued that environmental concerns will remain peripheral to national policy makers unless they can be connected to core state imperatives that have emerged over the longer evolution of the state (such as economic growth/modernisation or order/security). This suggests that developed states may indeed rise to be climate leaders if they succeed in framing and legitimating environmental policies in terms of ecological modernisation or national environmental or energy security.

In contrast, constructivist IR theorists emphasise that international norms can have constitutive effects on state identities and interests (e.g., Klotz 1995). So insofar as climate leaders have 'internalised' the international norms of climate leadership then this will reconstitute their state identities, interests and policy preferences. Yet this internalisation 
rarely takes the form of wholesale, unmediated acceptance. More typically, international norms are refashioned and 'localized' to fit in with domestic cultures (Acharya 2004). Moreover, as K.J. Holsti's pioneering work on foreign policy and role theory has shown, international role performance takes place within a system of role prescriptions that includes self-defined role conceptions and the role prescriptions emanating from the 'external environment' (1970, 240). Self-ascribed identities and international role conceptions do not necessarily entail the answerability to others that comes with the discharge of socially/internationally ascribed roles.

The purpose of this paper is to examine how climate leaders have legitimated their climate policy and diplomacy in order to explore to what extent the competing sceptical and constructivist accounts of climate leadership hold. To what extent are the discourses of climate leaders tethered to an internationalist or cosmopolitan role conception and to what extent are they yoked to traditional state purposes such as the promotion of national economic development and/or national security interests? These questions are addressed through a comparative analysis of the climate discourses of two states, Germany and Norway, which have the highest mitigation ambition over the period 2001-2014 relative to the other members of their respective developed country negotiation blocs (i.e., the European Union and the Umbrella group). The discourse analysis focuses on the text and talk of the political executive, since it serves as the linch-pin between domestic politics and international diplomacy, enjoys a privileged platform from which to narrate the meaning of national identity, national interests and international responsibilities and role conceptions and provides the primary cues for media reporting on national and international climate politics. The intuition is that if the ecological state is increasingly an international creation that is dependent on international cooperation, then it must be prepared, at least in some sense, to 
serve purposes beyond itself and become a 'local agent of the common good', to adopt Hedley Bull's notable phrase (Bull 1984, 14). If such enlarged purposes are missing from those states that most aspire to be climate leaders, then the scepticism of sociological theories of the ecological state would be vindicated and the prospects for the realisation of the normative vision of the ecological state (e.g. Eckersley 2014) would be dim.

The analysis begins with an explanation of the case study selection and methodology for the discourse analysis. This is followed by the two case studies of Germany and Norway, each of which begin with a brief overview of the climate policy history, along with some of the key political challenges confronting the governments of each country, to set the context for the discourse analysis that follows. The conclusion draws together and compares the main findings. The analysis shows that while ecological modernization discourses are prevalent in the climate discourses of both Germany and Norway they are knitted into larger assemblages that include discourses of 'enlarged responsibility' to others, albeit in uniquely Norwegian and Germany ways.

\section{Case Study Selection}

My concern is not to measure and critically assess climate leadership but rather to analyse how it is discursively produced and legitimated. This nonetheless requires the selection of climate leaders for the discourse analysis. Germany and Norway are the most interesting candidates for several reasons.

First, Germany and Norway stand out as leaders in terms of mitigation ambition within the EU and the Umbrella group respectively. Germany has the most ambitious targets over the 
near term (minus 40 percent by 2020 from a 1990 baseline). While Sweden and Denmark have also adopted the same target neither have enjoyed the same leadership reputation as Germany over the longer term. Norway's target of minus 30 percent by 2020 (rising to minus 40 percent if all major emitters commit to an agreement in line with the two degrees Celsius target) is significantly higher than other Umbrella group members.

Second, compared to other European countries with high mitigation ambition, Germany and Norway appear to have more reasons not to pursue overly ambitious mitigation reduction targets. They have much greater, ongoing economic and political dependencies on fossil fuels (coal for Germany, and oil/gas for Norway), which mark them out from Sweden, Denmark, France and to a lesser extent the UK. These dependencies create greater legitimation challenges.

Third, both Germany and Norway have disavowed nuclear power as energy options (Norwegian Ministry of the Environment [2007b]), and Germany has also abandoned carbon capture and storage (CCS). Both countries have also chosen costly energy policies as part of their climate strategies. Taken together, these additional challenges make Germany and Norway more interesting case studies to examine how their governments have legitimated their leadership ambitions.

\section{Methodology}

The meaning of national identities, and international roles and responsibilities, are no more or less stable than the political discourses that produce them. By discourse I mean a pattern of signification that constitutes particular problems, categories, forms of knowledge, ideas, 
values, beliefs, social identities, roles and responsibilities, and prescribes appropriate behaviour. Discourses respond to political contestation and complexity by seeking to impose order and stability on meaning, and therefore function as 'ordering devices' (Hajer and Laws 2006, 252). While there are notable epistemological and methodological differences among different schools of discourse analysis (particularly between critical discourse analysis and post-structural approaches) they nonetheless share the basic insight that discourses construct or produce, rather than simply reflect, social roles, responsibilities and identities.

The discourse analysis was conducted by searching for, and coding, regularities in the discursive structure of the talk and text of the political executive according to the most salient frames, storylines, rhetorical elements and, most importantly, subject positions. A frame (such as security, modernisation, or justice) is an ordering device that provides a singular way of viewing and interpreting particular phenomena that produces particular implications for social action. Yet common frames can be filled out in a variety of different ways according to different story lines, which provide narrative coherence and stake out particular subject positions within the narrative. Story lines are 'devices through which actors are positioned... and through which specific ideas of "blame" and "responsibility" and of "urgency" and "responsible behaviour" are attributed' (Hajer 1995, 65). A subject position is a linguistic category that refers to the self (the ' $\mathrm{I}$ ' or 'we') within the discourse, and it is the means by which identities are produced. This necessarily requires an 'other', since identity presupposes difference between self and other. Identities, including national imaginaries, provide answers to the ontological question 'who am I?' or 'who are we'? (Hopf 1998, 175). For poststructuralists, "identities are shaped by declarative acts of "nomination" - moments of naming in which political subjects are interpellated or "hailed" by major social institutions and producers of discourse' (Maynard 2013, 307). The creation of identities can short circuit 
the need for reasoned argument. That is, if the identity of country $\mathrm{X}$ is declared to be $\mathrm{Y}$, then $\mathrm{X}$ must conduct itself in according to the role and logic of appropriateness associated with the attributes of $\mathrm{Y}$ because this is who $\mathrm{X}$ is.

The discourses were characterised on the basis of an analysis of around 100 primary texts made up of speeches, press releases, media interviews, You Tube videos, and conference presentations. For Germany, this comprised primary texts from Chancellor Angela Merkel (2007-2014), Federal Environment Ministers Sigmar Gabriel (2007-2009); Norbert Röttgen (2009-2012); Peter Altmaier (2012-2013); Barbara Hendricks (2014, until October) and Federal Minister for Energy and Economic Sigmar Gabriel (2014, until October). For Norway, this comprised primary texts from the Prime Ministers Jens Stoltenberg (2007-2013) and Erna Solberg (2013-October 2014) and Environment Ministers Helen Bjørnøy (20052007); Erik Solheim (2007-2012); Bård Vegard Solhjell (2012-2013) and Tine Sundtoft (2013-October 2014).

Both international-facing and domestic-facing texts were examined, since both kinds of communication can now reach both international and domestic audiences. Only texts where climate policy formed a major component of the speech/video were selected, unless climate change or climate policy were mentioned in the context of speeches that were delivered on highly significant occasions, such as the Chancellor's or Prime Minister's address the nation, or speeches delivered at major international meetings or to the US Congress, or British or European Parliament. ${ }^{2}$ Most of the speeches were garnered from official government websites. A full list of the texts analysed is provided in Appendices 1 and 2. 
A discourse is validated when further reading of texts yields no change in the frames, storylines, and subject position (Milliken 1999). The validation of the discourses became very clear in both countries in relation to frames, storylines (including arguments) and subject position/role conception well before the completion of coding of half of the texts. Predictably, much more variation was found in the rhetorical elements used, which varied according to the speakers' different style, although some patterns were discerned. Since the primary focus of the analysis is the legitimation strategies of the political executive rather than policy detail, the latter was not systematically coded (and in any event, these details evolved considerably over the seven year period). However, a broad outline of the main policy developments in each country is provided as a prelude to the discourse analysis to provide context.

\section{Germany: the Burden of History}

In 2007, Chancellor Angela Merkel's federal 'grand coalition' (CDU, SPD and CSU) launched a new integrated climate and energy programme based on an ambitious emissions reduction target of $40 \%$ by 2020 (from a 1990 base), which also served as Germany's Copenhagen pledge in 2009. In the wake of the Fukushima nuclear disaster in 2011, Merkel (then leading a centre-right coalition with the CSU and the FDP) committed Germany to an accelerated phase out of nuclear energy, lifted Germany's renewable energy target to $35 \%$ by 2020 and $80 \%$ by 2050 and made Energiewende (the energy transition, turn or concept) the centre piece of Germany's climate and energy policy. Germany has sought to achieve its targets through a complex mix of policy instruments, including a very generous feed-in-tariff scheme, energy efficiency measures, ecological taxes, emissions trading and voluntary agreements with industry. Investment in CCS was initially part of this package but the government later closed down Germany's last remaining CCS pilot plant in 2011. 
While Germany's long term goal is to replace nuclear power and fossil fuels with renewable energy by 2015 , it faces a number of short and medium term challenges. The most significant domestic challenge has been rising energy prices as the share of renewable energy entering the grid has increased, since under the Renewable Energy Sources Act (EEA) the feed-in tariff is funded by a surcharge on electricity consumers (albeit with a special equalisation scheme that reduces electricity costs for emissions intensive industry). By 2014, renewable energy reached $25 \%$ of domestic power generation and German energy prices were around $48 \%$ of the EU average (EurActiv 2014a). This became a major issue for business groups in the run up to the 2013 federal elections, which after lengthy negotiations, produced a second grand coalition between Merkel's CDU/CSU and the SPD. After the election, Merkel's government responded to these concerns by introducing 'EEG 2.0', which marks the beginning of a long term strategy to gradually wind down support for renewable energy as it becomes increasingly competitive. While Germany has deployed expensive policy instruments to achieve its ambitious goals relative to most other countries (Michaelowa 2013) a strong political constituency has built up around energiewende and it remains popular. The party that was most critical of rising electricity prices in the 2013 election, the pro-business FDP, failed to make the five percent threshold for the first time since 1949.

The major international credibility challenge for Merkel's government is that Germany is in the paradoxical situation of being a renewable energy leader and net exporter of electricity in the European market while remaining dependent on coal (including coal imports) for a significant portion of its primary energy supply. Coal still provides around $45 \%$ of Germany's electricity generation (EurActiv 2014b) and coal power capacity is expected to increase in Germany by nearly 9 gigawatts by 2015 (Morris and Pehnt 2014, 15). Germany’s 
dependence on coal would have been much less pronounced if the price of permits in the EU's emissions trading scheme had not plummeted in 2008, which made coal-fired electricity much cheaper than gas. However, no new coal plants have been planned since the nuclear phase-out of 2011, the government expects Germany's dependence on coal-generated electricity to scale down as the price of carbon increases under the EU ETS, renewable energy becomes cheaper and the grid infrastructure is modernized.

Despite these challenges, there is a consensus among all the political parties (albeit with different levels of enthusiasm), that climate change is a serious and mostly human-caused problem, that failure to act will give rise to tragic consequences, that a precautionary path is the most responsible, that the costs of inaction are greater than the costs of action, and that Germany should accept ambitious mitigation commitments to contribute to the collective effort of reducing the risk of warming beyond two degrees Celsius.

All of these general arguments are clearly evident in the discourses identified over the period 2007-2014, albeit filtered through a variety frames and storylines. The four most salient frames are leadership, responsibility and green growth (especially, but not exclusively, via energiewende), with justice and security playing supporting roles. Justice is typically aligned with the responsibility frame while energy security forms a key feature of energiewende. All of the frames carry accompanying storylines and subject positions, and these are sometimes bundled together in a larger, composite assemblage. Leadership is typically tethered to responsibility to form a 'responsible leader' assemblage while green growth and energiewende are usually tied to energy security. These two broader assemblages will therefore be analysed together. A separate analysis of subject positions will follow. 
The terms 'leader', 'pioneer' and 'role model' are major leitmotifs in the German discourse. Germany is characterised as diplomatic leader in the international negotiations in urging and providing greater mitigation ambition and contribution to climate finance, a pioneer and role model in national climate and energy policy, and a technological and market leader in renewable energy. The discourse not only defines Germany as a role model but also reflects back international recognition of this role, putting Germany on show and also under pressure to make good on its promises (e.g. Röttgen 2011c and d; Hendricks 2014d). In her first major speech to the Bundestag after the 2013 election Chancellor Merkel declared that "no other country in the world has tried to change its energy as radically [as Germany]... and 'the world is watching with interest and disbelief wondering whether this transformation will succeed' (Merkel 2014a).

The German discourse creates intimate connections between responsibility, leadership and setting an example: 'We need the courage to go ahead, even if we cannot yet know for certain whether our partners will join us in all the actions that we ourselves feel are right' (Hendricks 2014a). Germany's diplomatic discourse accepts the UNFCCC's principles of CBDR and interprets them to mean that developed countries in general, and Germany in particular, have an international responsibility to take the lead in mitigation by virtue of their historical responsibility and superior economic capacity, and to assist developing countries in mitigation and adaptation (e.g. Merkel 2014d). The discourse has increasingly drawn attention to the growing emissions of the major emitters in the developing world and the need for these major emitters to do their 'fair share' if global aggregate emissions are to be reduced to safe levels (e.g, Röttgen 2014a). However, this has not been held up as a condition precedent for 
Germany's cooperation. Rather, exercising the responsibility to lead is both necessary to ensure international justice to developing countries and to break the collective action problem in the multilateral negotiations by persuading China and India to follow (Merkel 2009a). The discourse accepts the cosmopolitan ideal that all citizens, irrespective of nationality, have an equal right to the assimilative capacity of the atmosphere, which means that per capita emissions all countries should eventually converge in the longer run (e.g. Merkel 2011).

To my mind, equity in all its aspects - and particularly when it comes to climate protection - is a truly global issue. It is connected to justice, it is connected to how to shoulder shared responsibility and at the same time offer people the same opportunities. We know we are carrying a burden of history with us (Federal Chancellor Angela Merkel (2012).

While the 'burden of history' in this quote is intended to refer to the historical responsibility of all developed countries, Germany is sometimes singled out as having its own, unique set of special responsibilities (e.g., Merkel 2009b; Merkel 2011; Röttgen 2011a) and its own special burden of history (discussed further below).

Green growth, energiewende, and energy security

Germany's green growth discourse is based on the 'greater costs of inaction' storyline of the 2006 Stern Review (e.g. Merkel 2011; 2012; 2014d). That is, 'economic growth will in the long run be higher with ambitious climate targets than without them' (Merkel 2014d; Hendricks 2014e). Energiewende is the key strategy for achieving a decoupling of economic growth and emissions, but it is defended as having many more benefits: reducing dangerous 
hazards and harmful impacts (associated with nuclear power and climate change), promoting greater energy efficiency, enhancing energy security and driving new investment, technological innovation and green jobs. So '[e]ven without climate change there would be enough reasons to restructure our energy supply and change the way we use energy' (Merkel 2011).

Energiewende is also positioned within a broader narrative of responsibility by serving as the primary means by which Germany will discharge its international climate responsibilities. Merkel's discourse, in particular, has invoked the idea of energy transformation to found a new narrative not just for Germany but also for the European Union in troubled times, with investment in new energy infrastructure in the Union serving as a means of providing higher levels of cooperation, and ever closer union (e.g. Merkel 2010). Indeed, by 2014, the German discourse began to promote a global energiewende (Hendricks 2014b and c).

While the German discourse embraces and supports carbon markets, particularly the EU emissions trading scheme and the Kyoto Protocol's Clean Development Mechanism, there is no special preoccupation with least-cost solutions and an implicit understanding that addressing the climate challenge requires a regulatory state to guide and channel market behaviour towards socially desirable ends. Yet there are also limits as to how far Germany will expose its industry to competitive disadvantage from rising energy prices. The German discourse vis-à-vis the EU has been quite defiant in resisting any suggestion that the special equalisation scheme for industry under the EEA Act 2000 constitutes state aid under EU competition law. Nonetheless, rising energy prices have sometimes produced a defensive tone in the discourse. As Sigmar Gabriel, Minister for Economics and Energy in Merkel's third government, put it: 'The energy transition is sometimes interpreted abroad as the 
"romantic adventure" of a wealthy country' that may be putting its energy security at risk (Gabriel 2014). However, he goes on to summarily dismiss this as a misconception by arguing that, far from putting Germany's energy security at risk, the energy transition is strengthening it by, among other things, reducing Germany's dependence on imported fossil fuel. In short, although Energiewende is an ecological modernisation discourse that emphasises the economic virtues of technological innovation and greater energy efficiency, it cannot be reduced to this. It is also intimately tied to Germany's energy security needs and Germany's moral, regional and international climate leadership responsibilities. While Germany has used its Presidency of the Security Council in 2011 to promote a debate on climate change and international security the latter frame has not otherwise been a salient feature of the German discourse.

\section{German identity and international role conception}

Over the past few months, concern over the euro has dominated public debate, no doubt about it. But I wouldn't conclude that people are no longer interested in climate protection. This issue has deep roots in Germany, both in terms of the dangers and the economic opportunities. In comparison to nations like the US, we should recognize this as a highly positive cultural characteristic of our country. (German Environment Minister, Norbert Röttgen (2011b).

The German discourse on climate change rarely makes explicit reference to the virtues of the German nation as a basis for legitimating Germany's climate and energy policy, or Germany's role in the development of EU or international climate policy. Norbert Röttgen's reference (quoted above) to the 'highly positive cultural characteristic of our country' (as a 
self/other comparison with the US) is the only reference that could be found. Instead, the German discourse (usually implicitly but sometimes explicitly (e.g. Merkel 2007a; 2014b) accepts that the German nation has, in its past, not been virtuous, and that Germany carries this heavy burden of history.

While the discourse on German national identity is muted, the discourse on European identity is much more explicit. Germany's role conception is intimately tied to Germany's place in post-1945 Europe, especially since unification following the fall of the Berlin Wall in 1989. This is most explicit in the discourses of Angela Merkel. For instance, in a speech to the European parliament as President of the Council, Merkel employed the refrain 'tearing down the wall' to end the divide between nations, between rich and poor, and between present and future generations (Merkel 2009a). She has also evoked the idea of the EU as both a house and a home, and declared that '...I don't ever want to leave this house. I am convinced that there is no better place for us to live than in our shared European home' (my emphasis) (Merkel 2007a). For Merkel, Europe's identity is ultimately anchored not in freedom but in tolerance: 'Europe's soul is tolerance. Europe is the continent of tolerance'. This means actively welcoming 'otherness', and striving for 'harmony among nations' as 'the greatest goal of the European unity'. This identity is runs deep precisely because it has been hard won:

We have taken centuries to learn this. On the way to tolerance we had to endure cataclysms. We persecuted and destroyed one another. We ravaged our homeland... Not even one generation has passed since the worst period of hate, devastation and destruction. That was perpetrated in the name of my people (Merkel 2007a). 
It is against this background of Europe as a successful work of peace, cooperation and tolerance (albeit still a work in progress), that Merkel (as President of the Council) is able to move on to declare Europe's role in climate change to be a 'pioneering role'. While the German discourse avoids the question of what it means to belong to the German nation, it is clear about what it means for Germany to belong to Europe, and Germany's self-ascribed roles and responsibilities as a responsible leader in Europe and the larger world are presented as flowing naturally from this positioning.

\section{Norway: The Good and Fortunate State}

Prior to the formation of Prime Minister Jens Stoltenberg's coalition government (20052013), made up of his Labour Party, the Socialist Left Party and the agrarian Centre Party) the Norwegian national climate debate had been preoccupied with the question of whether Norway should discharge its climate responsibilities through domestic action to avoid 'outsourcing responsibility', or whether international action (through carbon trading and offsetting) was more appropriate and cost-effective given the international nature of the problem (Hovden and Lindseth 2004). Jens Stoltenberg had a long history of defending international carbon markets, and under his leadership the international action discourse prevailed, albeit with some significant compromises. In 2007, the Stoltenberg government released a Climate White Paper that launched Norway's quest to become the world leader in climate change (Norwegian Ministry of the Environment 2006-2007). This included a voluntary upgrade of its original Kyoto target by ten percent, corresponding to a new target of minus nine per cent below the 1990 levels by 2008-2012. The White Paper committed Norway to a unilateral reduction of emissions of 30 per cent by 2020 (from 1990 levels), 
rising to minus 40 percent if there is agreement among the major emitters to reduce emissions consistent with a two degrees scenario, subject to continuation of the flexibility mechanisms. The Paper also declared that Norway would aim for complete carbon neutrality by 2050 (or by 2030 if an ambitious global agreement is reached). These ambitious goals were were backed by six of the seven parties (the exception was the Progress Party) in the Storting (the Norwegian parliament) in a political settlement reached in January 2008.

Stoltenberg's coalition held on to government after the 2009 elections, but lost power after the 2013 elections to a centre-right minority coalition government between the Conservative Party, led by Erna Solberg and the right-wing populist Progress Party, which entered government for the first time. Although climate change has generally been a lower priority for the Conservative Party (and especially for the Progress Party) than for the other parties in Norway, the Solberg minority government has nonetheless remained committed to the parliamentary settlement reached in 2008 and has sought to build on this settlement. Diplomatically, the new government has reaffirmed Norway's ambition to lead and has signalled that it will develop a 'carbon budget type commitment' in its post 2020 contribution to the proposed 2015 agreement (Sundhoft 2014g).

Despite having the advantages of an abundant supply of hydro-electricity (which covers around 99\% of electricity generation), Norway’s emissions are rising in manufacturing, transport and offshore gas and petroleum activities, so marginal abatement costs are high. This has created a major challenge for meeting the ambitious targets in the parliamentary settlement. Norway's key policy instruments for achieving domestic emissions reductions include a rise in the carbon tax (which had been introduced in 1991), emissions trading (linked into the EU emissions trading scheme), various other smaller measures designed to 
encourage public and low emission transport and decarbonize heating in buildings, and investment in CCS. While the development of robust international carbon markets remains important for the success of Norway's national climate policy, the parliamentary settlement required around two thirds of Norway's emissions to be made domestically. Moreover, Norway's significant investment in reducing emissions from deforestation in developing countries is not to be counted towards the achievement of Norway's 2020 target.

Against this background, the most contentious debate in Norwegian climate politics since the parliamentary settlement has been whether and/or how to proceed with new gas-fired power plants to meet shortfalls in energy production. The compromise that emerged, which was at odds with Stoltenberg's long-standing support for least-cost, market-based policy instruments, was that no new licenses to construct onshore gas-fired power stations would be provided unless they included CCS, and that state-owned companies would be created and state financial assistance would be provided to help ensure the success of CCS. As we shall see, this has required some faith and heroism on the part of the Stoltenberg government.

The Norwegian discourse routinely declares climate change to be one of the most significant challenges facing the world. Climate science, particularly the assessment reports of the IPCC, is treated as authoritative, and is reinforced by Norway's experience as an Arctic nation, where the effects of global warming are more rapid, visible and alarming. The Norwegian discourse accepts without question the responsibility of developed countries to lead in mitigation, adaptation, climate finance and the provision of other forms of assistance to developing countries, and for Norway to assume this responsibility without waiting for other developed countries to act. This includes committing to a second commitment period of the Kyoto Protocol. Like the German discourse, the Norwegian discourse argues that all major 
emitters must be part of a new agreement if the two degree Celsius guardrail is to be upheld, given the shrinking proportion of global emissions covered by the Kyoto Protocol (now less than 15 percent from a high of 50 percent). However, unlike Germany, Norway has deployed conditionality in its diplomacy in relation to its promise to increase its 2020 target to from minus 30 to minus 40 percent (as noted above).

The key discursive challenge for both the Stoltenberg and Solberg governments after the parliamentary settlement of 2008 has been to manage and minimize the tensions between Norway's role as an ambitious climate leader and its economic role as a major petroleum and gas producer. This tension has been managed in two broad, overlapping discourses. The first is built on a 'tackle poverty through development' frame, which seeks international justice in development and focuses on Norway's international responsibility to address the twin challenge of poverty and climate change. The second is framed around Norway's role as a technological pioneer that is positioned in the context of Norway's 'rags to riches' story of industrialization and modernization. These two overlapping discourses are supported by ancillary discourses on the virtues of carbon markets, overseas investment in rainforest protection, and CCS.

\section{International responsibility for the protection of the climate and the poor}

Norway's understanding of its international responsibility to address climate change is intimately tied to its broader overseas development philosophy that seeks to reduce inequalities of wealth, income and opportunity in the world and close the development gap. The problems of poverty (including energy poverty) and climate change are routinely identified as twin global challenges that must be addressed simultaneously by providing the 
financial and other resources to enable low-carbon development, along with payments for forest protection, in developing countries (Solberg 2013a). The Norwegian responsibility narrative accepts that rich countries have produced most of the historical emissions and must accept the consequences of their prosperity, that poor countries should not be denied the right to develop and therefore rich countries have an obligation to help poor countries 'jump over the most polluting stages in the economic development' (Solheim 2007a). The discourse positions Norway as a 'global leader for a strong international agreement in 2015 ' (e.g., Sundhoft 2014f), a generous contributor to climate finance and a major investor in reducing emissions from deforestation in developing countries.

These various responsibilities arise by virtue of Norway's status as one of the richest countries in the world, from its self-understanding as a good state and a good people (discussed further below) and from its role as a major exporter of oil and gas, which confers 'a particular responsibility to provide a more climate friendly option for using fossil fuels, including coal, during the transition to a low carbon energy system' (Solheim 2008a; see also Bjørnøy 2007f). The need for universal access to energy and poverty alleviation is therefore directly connected to, and realized by (among other things), Norway's pioneering role in promoting new technologies such as CCS. Norway's prominent role in promoting Reduced Emissions from Degradation and Deforestation (REDD) is also a key plank in Norway's response to the global effort to reduce emissions. Investment in avoided deforestation is defended as the fastest, cheapest and most efficient way of achieving big cuts in global emissions (Stoltenberg 2011c). Forests are portrayed as 'nature's own carbon capture and storage facility' (Stoltenberg 2010c; 2012d), producing a fitting symmetry with Norway's efforts to promote CCS. 
Technological Pioneership, Norway's modernization and the story of oil and gas

Like Germany, the Norwegian discourse frames Norway's role as a climate pioneer, examplesetter, front-runner and leader. 'Pioneer' is the most popular in this list. Norway is much admired for its courageous pioneers: 'Nansen and Amundsen conquered the ice. Our goal must be to prevent the ice from melting' (Stoltenberg 2011a). Norway was the first country to introduce a CO2 tax for the petroleum industry and 'Most other oil-exporting countries were shocked by that' (Stoltenberg 2007c; Solheim 2007a). Norway is also a pioneer in developing CCS technologies (Stoltenburg 2008b).

Norway's roles as a technological pioneer are knitted into a larger narrative of Norway’s industrial transformation from a nation of poor farmers and fishers at the beginning of the twentieth century to one of the richest countries in the developed world (e.g. Stoltenberg 2011a). The 'pioneering generation' built up the Norwegian welfare state (Stoltenberg 2010a), but it was the oil wealth that consolidated and strengthened it: 'The Egyptians built the granaries. We built the Government Pension Fund - Global' (Stoltenberg 2010a; 2012b). The story of Norway's growing prosperity and accompanying responsibility is based on both luck and good management: 'Norway has a big responsibility because we've been lucky. We found oil in the North Sea, and we have managed our lucky lottery ticket well' (Sundhoft, 2013a). Norway is only lucky but also inventive and is therefore able to continue the story of prosperity by enacting its climate leadership through sound environmental management and technological ingenuity. The Norwegian petroleum and gas industry are part of this leadership story because it is more environmentally friendly compared to elsewhere, and when gas is sold into the Nordic or European electricity market is able to replace dirtier 
sources such as coal. Norwegian gas and CCS can also serve as bridges towards a low carbon future (e.g., Bjørnøy 2007f; Stoltenberg 2010c).

The most emblematic speech on Norway's technological pioneership and heroism is Stoltenberg's 'moon landing' speech, delivered to the nation in the new year of 2007:

We must take our share of responsibility. Greenhouse gas emission must be reduced. Norway has taken on a pioneering role by deciding that the gas power plant at Mongstad will be required to have full-scale $\mathrm{CO} 2$ capture and storage (CCS). We are going to make this a reality...This will be an important breakthrough in the efforts to reduce greenhouse gas emissions in Norway, and once we succeed, I am convinced that the rest of the world will follow our example. This is a major project for our country. It is our moon landing (Prime Minister Jens Stoltenberg, 2007a)

CCS thus provides the means for resolving the 'paradox' of Norway as a major petroleum and gas exporter and a climate leader. ${ }^{3}$

Erna Solberg's new centre-right coalition has legitimated its continuing commitment to the parliamentary settlement of 2008 on the basis of a classic conservative 'stewardship ethic' and the precautionary principle (Solberg 2013a), blended with an ecological modernisation narrative based on technological innovation. Although the Mongstad CCS project is now doubtful, the new government remains committed to CCS and has continued to portray the Norwegian petroleum industry as environmentally responsible. 
The Norwegian subject is most on display in the Prime Minister's new year's eve addresses, which rejoice in the qualities of Norway as a good and fortunate country, 'a good place to live' (e.g. Stoltenberg 2007a), and of Norwegians as pioneering, courageous, good, warm, happy, optimistic and responsible (Stoltenberg 2009a). However, with opportunity and privilege comes responsibility: 'It is therefore important that we seek at all times to do more for those who have least'; 'We must promise one another that we will not give up the deep Norwegian commitment to help the world's poor' (Stoltenberg 2009a).

The Norwegian subject is also cooperative, with 'a culture of making an effort together' (Stoltenberg 2009a). Reference is often made to the unique Norwegian word dugnad, which means 'working together for the common good...It is a valuable aspect of our national character' (Stoltenberg 2009a):

A dugnad is when a community makes a joint effort to do a job which needs to be done, which is in everyone's interest, and which can only be done when a large group cooperates. And what everyone does, counts. Dugnads are done all the time in Norway. Now we need an international climate dugdad (Solhjell 2012f)

Norway's willingness to commit to global action in the service of the common good means that it is sometimes able to play a greater role in the world than its small size would suggest (Stoltenberg 2010a): 'We have been entrusted with a legacy that spans from Nansen's dedication to helping refugees to Gro Harlem Brundtland's international leadership in environmental issues. This means we must continue to take responsibility' (Stoltenberg 2010a). In short, 'a society with low greenhouse gas emissions is a good society' (Sundhoft 
2013a) and since Norway is a good society and a responsible state it follows naturally that Norway must pursue this option at home and abroad.

\section{Conclusion}

It is clear from the foregoing analysis that the German and Norwegian governments have depended heavily on discourses of green growth and ecological modernisation in legitimating their domestic climate and energy policies. This is hardly surprising, given that the modern state is both a key agent as well as a product of the broader processes of modernisation, and that the ecological modernisation discourse can sit comfortably with most political ideologies. Yet this does not fully vindicate the more sceptical theories of the ecological state since the more significant finding is that neither the German nor Norwegian climate discourses can be reduced to the so-called narrow or 'weak' technological version of ecological modernisation, as characterized by Christoff (1996). Rather, the modernization frame is linked, through different 'chains of equivalence', with different national or regional imaginaries and purposes to reveal reflexive rather than simple accounts of ecological modernization that embrace larger responsibilities. By 'reflexive' I mean not simply critically reflecting on the conditions for the sustained reproduction and flourishing of the nation, state and economy in a globalised world but also critical reflection on the consequences for others in space and time. Both the German and Norwegian climate discourses not only embrace climate leadership but also evoke, either explicitly or implicitly, a cosmopolitan narrative of connections to, and 'enlarged responsibility' towards, others in a global community. The same can be said of the security frame, which was prominent in the German discourse (but largely absent from the Norwegian discourse). While energiewende includes a concern for Germany's energy security, the German discourse reaches out beyond the borders of Germany to include the 
energy security of the European Union and, more tentatively, the world, and Germany has also promoted a debate on climate change and international security in the UN Security Council.

The analysis is broadly consistent with constructivist claims about the relationship between norms, identities and social roles. It also highlights the different ways in which the internationally ascribed leadership obligations and norms of CBDR are appropriated, calibrated and legitimated in nationally specific ways in accordance with different identities and roles conceptions. This is not to suggest a stable or perfect fit, far less to suggest that these roles have been fully and faithfully enacted. But the identity that is summoned in the discourse nonetheless provides a rationale for fulfilling the international obligations and norms.

The Norwegian climate discourse is the most explicit about what it means to be Norwegian, and about Norway's role in the world, which is to be good and benevolent towards others who are less fortunate because Norway is blessed with good fortune and wishes to extend this to others. The Norwegian state has been closely tied to forces on the centre-left for more than 100 years, and this has helped to shape a mostly benevolent, internationalist and sometimes cosmopolitan foreign policy (Østerud and Selle 2006, 26). However, as we have seen, moral responsibility and technological heroism are fused in particular ways that allow Norway to continue to exploit its significant offshore oil and gas resources for the foreseeable future. The German discourse is more subdued about national identity and much more explicit about European identity, and what it means to belong to and serve Europe and the European project in the post-World War II period. This is to continue the work of making Europe a successful work of peace and cooperation for the common good. Germany's discourse suffers less role 
strain than Norway. The problem of coal dependence is brushed aside as if it were a small thorn in the side that will be removed in the medium term.

The Norwegian and Germany discourses stand in stark contrast to the climate discourses of other fossil fuel dependent countries in the developed world, most notably the governments of Canada and Australia, which have resisted the international call for climate leadership, highlighted the short-term costs of action and 'talked up' the future of fossil fuels. This suggests that a close study of discourses of national identities and international role conceptions may provide stronger clues than a simple calculation of relative fossil fuel dependence in revealing which states are more likely to be hailed by multilateral environmental norms and evolve into more fully fledged ecological states. 


\section{References}

Acharya, A. (2004) 'How ideas spread: whose norms matter? Norm Localization and Institutional Change in Asian Regionalism'. International Organization 58(2): 239-275.

Alstadheim, K. B., and Stoltenberg, J. (2010) Klima paradokset [The Climate Paradox]: Jens Stoltenberg om vår tids største utfordring. Oslo, Aschehoug.

Bull, H. 1984 Justice in international relations: the Hagey lectures. Waterloo, Ontario: University of Waterloo).

Christoff, P. 1996. 'Ecological Modernisation, Ecological Modernities'. Environmental Politics 5 (3): 476-500.

Dryzek, J. S., 1992. 'Ecology and discursive democracy: beyond liberal capitalism and the administrative state', Capitalism, Nature, Socialism 3(2): 18-42.

Dryzek, J. S., Downes, D., Hunold, C., Schlosberg, D. \& Hernes, H. 2003., Green states and social movements: environmentalism in the United States, United Kingdom, Germany and Norway (Oxford University Press, Oxford).

Eckersley, R., 2004. The green state: rethinking democracy and sovereignty (Cambridge, MA: The MIT Press). 
EurActiv. 2014a. 'German energy prices 50\% higher than EU average: McKinsey', 7

February. Available at: http://www.euractiv.com/sections/energy/german-energy-prices-50higher-eu-average-mckinsey-269844 (accessed 9 November 2014)

EurActiv 2014b. 'Germany may cut coal-fired energy to protect climate'. 30 October.

Available at: http://www.euractiv.com/sections/energy/germany-may-cut-coal-fired-energyprotect-climate-309617?utm source=EurActiv+Newsletter\&utm campaign=78ade63b7dnewsletter daily update\&utm medium=email\&utm term $=0$ bab5f0ea4e-78ade63b7d$\underline{245356673}$ [Accessed 4 November 2014]

Gabriel, S., 2014. Completing the energy transition: interview with Minister for Economics and Energy Sigmar Gabriel. Deutschland.de [online]. Available from: http://www.london.diplo.de/Vertretung/london/en/04/Science/Emergy-Transition.html [Accessed 28 October 2014]

Hajer, M.A. 1995. The politics of environmental discourse: Ecological modernization and the policy process. New York, NY: Oxford University Press.

Hajer, M. and Laws, M. 2006. 'Ordering through discourse', in The Oxford Handbook of Public Policy, edited by Michael Moran, Martin Rein and Robert Goodin (Oxford: Oxford University Press), 251-268.

Hay, C., 1996. 'From crisis to catastrophe?: the ecological pathologies of the liberaldemocratic state', Innovations 9(4): 421-34. 
Hendricks, B., 2014a. Statement at the opening of the $5^{\text {th }}$ Petersberg Climate Dialogue. Berlin. Federal Ministry for the Environment, Nature Conservation, Building and Nuclear Safety [online]. 14 July 2014. Available from: www.bmub.bund.de/N50976-1/ [Accessed 28 October 2014]

Hendricks, B., 2014b. Statement at the UN Climate Summit theme Energy 'multilateral and multi-stakeholder action announcements'. In New York. Federal Ministry for the Environment, Nature Conservation, Building and Nuclear Safety [online]. 23 September 2014. Available from: www.bmub.bund.de/N51201-1/ [Accessed 28 October 2014]

Hendricks, B., 2014c. Statement at the UN Climate Summit theme cities and climate change. New York. Federal Ministry for the Environment, Nature Conservation, Building and Nuclear Safety [online]. 23 September 2014. Available from: www.bmub.bund.de/N51193-1/ [Accessed 28 October 2014]

Hendricks, B., 2014d. Statement at the UN Climate Summit. New York. Federal Ministry for the Environment, Nature Conservation, Building and Nuclear Safety [online]. 24 September 2014. Available from: www.bmub.bund.de/N51196-1/ [Accessed 28 October 2014]

Hendricks, B., 2014e. Press release: Industry is a key partner for climate action. Berlin. No. 190/14. Federal Ministry for the Environment, Nature Conservation, Building and Nuclear Safety [online]. 13 October 2014. Available from: www.bmub.bund.de/N51218-1/ [Accessed 28 October 2014] 
Holsti, K.J., 1970. 'National Role Conceptions in the Study of Foreign Policy', International Studies Quarterly 14(3): 233-309.

Hopf, T. 1998. 'The promise of constructivism in international relations theory', International Security 23 (1): 171-200.

Hovden, E. \& Lindseth, G., 2004. 'Discourses in Norwegian climate policy: national action or thinking globally?', Political Studies 52 (1): 63-81.

Klotz, A. 1995. Norms reconstituting interests: global racial equality and U.S. sanctions against South Africa. International Organization 49 (3): 451-78.

Maynard, J.L. 2013. A map of the field of ideological analysis', Journal of Political Ideologies 18 (3): 299-327.

Meadowcroft, J., 2005. 'From welfare state to ecostate' in J. Barry and R. Eckersley, eds. The State and the Global Ecological Crisis. Cambridge, MA, MIT Press.

Merkel, A. 2007a. Speech to the European parliament. Wikisource [online]. 17 January 2007. Available from:

http://en.wikisource.org/wiki/Angela Merkel's 2007 Speech to the European Parliament [Accessed 29 October 2014] 
Merkel, A. 2009a. Speech before the United States Congress. Washington. 3 November 2009. Available from: Spiegel [online], 'We have no time to lose' (reported on 4 November 2009). Available at: http://www.youtube.com/watch?v=C2W2qGDRHU8 [Accessed 29 October 2014]. Transcript available from: http://www.spiegel.de/international/europe/angela-merkels-speech-we-have-no-time-t+o-lose-a-659196.html

Merkel, A., 2009b. Speech to UN Climate Conference. 17 December 2009. Available from: http://www.bundesregierung.de/Content/EN/Artikel/2009/12/2009-12-17$\underline{\text { regierungserklaerung_en.html }}$

Merkel, A., 2010. Speech by federal chancellor Angela Merkel at the opening ceremony of the 61 st academic year of the College of Europe, 2 November. Available at: http://www.bruessel.diplo.de/contentblob/2959854/Daten/ (accessed 3 March 2014).

Merkel, A., 2011 Speech at Second Petersberg Climate Dialogue. Berlin. The Federal Government [online]. 3 July 2011. Available from: http://www.bmub.bund.de/N47612-1/ [Accessed 28 October 2014].

Merkel, A., 2012. Speech by federal chancellor Angela Merkel at the Petersberg Climate Dialogue III, Berlin, 16 July. Available at: http://www.bundesregierung.de/ContentArchiv/EN/Archiv17/Reden/2012/2012-07-19-rede-

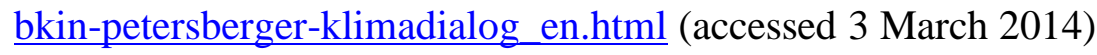


Merkel, A., 2014a. State of the Nation address to the German parliament. DW Media Center [online]. 29 January 2014. Available at: http://www.dw.de/merkel-commits-a-renewableenergy-economy-in-major-policy-speech/av-17394019 [Accessed 5 November 2014] NEED FULL TRANSLATION

Merkel, A., 2014b. Speech to British parliament. London. 27 February 2014. Available from: http://www.bundesregierung.de/Content/EN/Reden/2014/2014-02-28-brit-parlament-en.html http://www.youtube.com/watch?v=lmusV-7BMzM [Accessed 28 October 2014]

Merkel, A. 2014d. Speech at the Fifth Petersberg Climate dialogue. Berlin. 14 July 2014. Available from: http://www.bundesregierung.de/Content/EN/Reden/2014/2014-07-14petersberg-climatedialogue en.html;jsessionid=055461F7C12A906F7B552590E9C351AA.s4t2?nn=393812 [Accessed 28 October 2014]

Millikin, J. 1999. 'The study of discourse in international relations: a critique of research and methods', European Journal of International Relations 5 (2): 225-54.

Michaelowa, A. 2013. 'The politics of climate change in Germany', WIRE's Climate Change 4 (2013): 315-310.

Morris, C. and Pehnt, M. 2014. Energy transition: the German energiewende. (no date) (Berlin: Heinrich Böll Stiftung) 
Norwegian Ministry of the Environment., 2006-2007. Norwegian climate policy: summary in English: report no. 34 (2006-2007) to the Storting. Available at:

http://www.regjeringen.no/en/archive/Stoltenbergs-2nd-Government/Ministry-of-theEnvironment/Nyheter-og-pressemeldinger/pressemeldinger/2007/new-measures-to-reachnorways-ambitious-.html?id=473402 (accessed 3 March 2014).

Norwegian Ministry of the Environment. 2007a. Press Release: new measures to reach Norway's ambitious climate targets. Government.no [online]. 22 June 2007. Available from:http://www.regjeringen.no/en/archive/Stoltenbergs-2nd-Government/Ministry-of-theEnvironment/Nyheter-og-pressemeldinger/pressemeldinger/2007/new-measures-to-reachnorways-ambitious-.html?regj_oss=1\&id=473402 [Accessed 30 October 2014]

Norwegian Ministry of the Environment 2007b. Press Release: Environment ministers warn against nuclear power as a solution to the climate crisis', October 2007. Available from: http://www.regjeringen.no/Upload/MD/Vedlegg/Internasjonalt/Vienna_Ministerial_Statement 071001.pdf [Accessed 29 October 2014]

Østerud, Ø.\& Selle, P., 2006. 'Power and democracy in Norway: the transformation of Norwegian politics', Scandinavian Political Studies 29 (1): 25-46.

Röttgen, N., 2011a. Statement at high level segment of the UNFCCC2011 COP17 and CMP 7. Durban. Federal Ministry for the Environment, Nature Conservation and Nuclear Safety [online]. 7 December 2011. Available from: www.bmub.bund.de/N48122-1/ [Accessed 6 November 2014] 
Röttgen, N., 2011b. German Environment Minister: 'Our lifestyle has revolved around a dangerous egotism', Spiegel online. Available at:

http://www.spiegel.de/international/germany/german-environment-minister-our-lifestyle-hasrevolved-around-a-dangerous-egotism-a-800288.html [accessed 3 March 2014].

Röttgen, N., 2011c. Press release: Germany honoured for resolute expansion of renewable energies. No. 158/11. Federal Ministry for the Environment, Nature Conservation and Nuclear Safety [online]. 5 December 2011. Available from: www.bmub.bund.de/N48099-1/ [Accessed 6 November 2014]

Röttgen, N., 2011d. Speech on Germany's low carbon and energy strategy. Side Event COP 17 Durban. Federal Ministry for the Environment, Nature Conservation and Nuclear Safety [online]. 7 December 2011. Available from: www.bmub.bund.de/N48119-1/ [Accessed 28 October 2014].

Stoltenberg, J., 2007a. Statsministerens konto, Prime Minister Jens Stoltenberg's new year's address, 1 January 2007 http://www.regjeringen.no/nb/dep/smk/aktuelt/taler_og_artikler/statsministeren/statsminister jens_stoltenberg/2007-4/statsministerens-nyttarstale-2007/new-years-address.html?id=445669 (accessed 3 March 2014). 
Stoltenberg, J., 2009a. New Year address to the Norwegian People. Oslo. Office of the Prime Minister archive [online]. 1 January 2009. Available from: http://www.regjeringen.no/en/dep/smk/Whats-new/Speeches-andarticles/statsministeren/statsminister_jens_stoltenberg/2009/prime-ministers-new-yearsaddress-2009.html?id=541382 [Accessed 20 January 2011].

Stoltenberg, J., 2010a. New Year address to the Norwegian People, Oslo. 1 January 2010. Available from: http://www.regjeringen.no/en/dep/smk/Whats-new/Speeches-andarticles/statsministeren/statsminister_jens_stoltenberg/2010/prime-ministers-new-yearsaddress-2010.html?id=589483 [Accessed 20 January 2011].

Stoltenberg, J., 2010c. Speech at Offshore Northern Seas. Stavanger. Office of the Prime Minister archive [online]. 24 August 2010. Available from:

http://www.regjeringen.no/en/dep/smk/Whats-new/Speeches-andarticles/statsministeren/statsminister jens stoltenberg/2010/speech-at-offshore-northern-

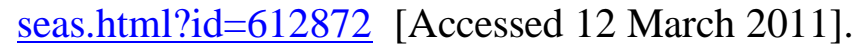

Stoltenberg, J., 2011a. New Year address to the Norwegian People. Oslo. Office of the Prime Minister archive [online]. 1 January 2011. Available from: http://www.regjeringen.no/en/dep/smk/Whats-new/Speeches-andarticles/statsministeren/statsminister jens stoltenberg/2011/prime-minister-jens-stoltenbergsnew-yea.html?id=629901 [Accessed 12 March 2011]. 
Stoltenberg, J. 2011c. Speech during the high level segment at COP17. Durban, South Africa. Office of the Prime Minister archive [online]. 7 December 2011. Available from: http://www.regjeringen.no/en/dep/smk/Whats-new/Speeches-and-

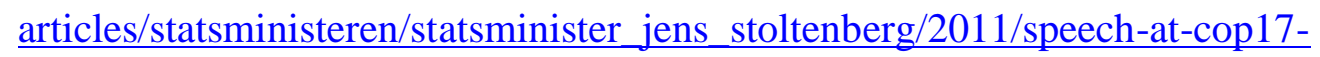
. html?id=665751 [Accessed 17 January 2012].

Stoltenberg, J., 2012b. Speech at Oslo Energy Forum 2012. Holmenkollen Park Hotel, Oslo. Office of the Prime Minister archive [online]. 8 February 2012. Available from: http://www.regjeringen.no/en/dep/smk/Whats-new/Speeches-andarticles/statsministeren/statsminister_jens_stoltenberg/2012/oslo-energy-forum2012.html?id=671823 [Accessed 9 September 2012].

Stoltenberg, J., 2012d. Moving towards sustainability: together we must create the future we want. Rio+20 conference, Rio de Janeiro, Brazil, Office of the Prime Minister archive [online]. 20 June 2012. Available from: http://www.regjeringen.no/en/dep/smk/Whatsnew/Speeches-and-articles/statsministeren/statsminister_jens_stoltenberg/2012/moving$\underline{\text { towards-sustainability-together-w.html } ? \mathrm{id}=686601}$ [Accessed 9 September 2012].

Sundhoft, T., 2013a. Speech at the Zero Conference. Oslo. Ministry of Climate and Environment website [online]. 7 November 2013. (Norwegian): Available from: http://www.regjeringen.no/nb/dep/kld/aktuelt/taler artikler/ministeren/2013/tale-pa-zerokonferansen.html?id=745178 [Accessed 14 January 2014]. English translation by Dina Hestad. 
Sundhoft, T., 2014f. Opening statement: breaking the climate stalemate. Ny Alesund Symposium. 26 May 2014. Available from: http://www.regjeringen.no/en/dep/kld/Whatsnew/speeches-and-articles/the-ministers-speeches-and-articles/2014/Opening-statementBreaking-the-Climate-Stalemate.html?id=761061 [Accessed 5 November 2014]

Sundhoft, T., 2014g. Speech at ministerial meeting Kyoto Protocol. Bonn climate change Conference. 5 June 2014. Available from: http://www.regjeringen.no/en/dep/kld/Whatsnew/speeches-and-articles/the-ministers-speeches-and-articles/2014/Speech-Ministerial$\underline{\text { meeting-KP-2.html?id=762288 }}$ [Accessed 5 November 2014] 


\section{Notes}

${ }^{1}$ See also Articles 3(2), 3(3) and 4(5) of the UNFCCC.

${ }^{2}$ While all of the international-facing speeches were available in English, and most of the significant domestic-facing texts were also available in English translations, some of the domestic-facing texts were not available in English translation. In the case of Norway, the most significant Norwegian language texts were read, and excerpts were translated, by a Norwegian speaking research assistant. In the case of Germany, the untranslated speeches and videos were read/viewed by a German speaking research assistant to check whether the discourses that had been identified from the English texts by the author were also validated in the German texts. No adjustments were required.

${ }^{3}$ Stoltenberg wrestles with these tensions in Klima Paradokset: Jens Stoltenberg om vår tids største utfordring, a book based on a long interview with the journalist Kjetil Alstadheim (2010). 


\section{University Library}

\section{- M M N E R VA A gateway to Melbourne's research publications}

Minerva Access is the Institutional Repository of The University of Melbourne

Author/s:

Eckersley, R

Title:

National identities, international roles, and the legitimation of climate leadership: Germany and Norway compared

Date:

2016-01-02

Citation:

Eckersley, R. (2016). National identities, international roles, and the legitimation of climate leadership: Germany and Norway compared. ENVIRONMENTAL POLITICS, 25 (1), pp.180-201. https://doi.org/10.1080/09644016.2015.1076278.

Persistent Link:

http://hdl.handle.net/11343/261035 